\title{
The impact of ecocommunity-based tourism development
}

\section{Dampak pengembangan pariwisata berbasis ekowisata dan komunitas}

\author{
Oman Sukmana \\ Department of Social Welfare, Faculty of Social and Political Sciences, \\ University of Muhammadiyah Malang \\ Address: Jalan Tlogomas No. 246 Malang, East Java Province, Indonesia 65144 \\ E-mail: oman@umm.ac.id
}

Article History: Received 24 February 2021; Accepted 14 February 2022; Published Online 07 March 2022

\begin{abstract}
Batu City as a tourism city in Indonesia has a significant impact on its citizens. This study aims to describe the impact of the development of Batu City as a tourism city through the Ecocommunity-Based Tourism (ECBT) model on job growth and poverty reduction. This was qualitative research, in which the technique of collecting data was done through documentation, interviews, and observation. The results showed that Batu City was developed as a tourism city based on ECBT which is a combination of Ecotourism (ET) and Community-Based Tourism (CBT). The development of Batu City as a tourism city has a positive effect on employment growth of 1,074 types of employment in 2013 and increased to 6,183 types of employment in 2017. The increase in employment in the tourism industry sector also has an impact on reducing poverty levels, with the percentage of poor people in Batu City decreasing from 4.67 percent in 2013 to 4.31 percent in 2017. Other research findings also show that the migration of job seekers out of Batu City tends to be low, while the migration of job seekers into Batu City tends to be high. This study concludes that the development of tourism in Batu City is effective in creating jobs and reducing poverty levels.
\end{abstract}

Keywords: ecocommunity-based tourism; employment development; poverty reduction

\begin{abstract}
Abstrak
Kota Batu sebagai kota pariwisata di Indonesia memiliki dampak signifikan bagi warganya. Penelitian ini bertujuan untuk menggambarkan dampak pengembangan Kota Batu sebagai kota pariwisata melalui model EcocommunityBased Tourism (ECBT) terhadap pertumbuhan lapangan kerja dan pengurangan angka kemiskinan. Penelitian ini merupakan penelitian kualitatif, di mana teknik mengumpulkan data dilakukan melalui dokumentasi, wawancara, dan observasi. Hasil penelitian menunjukkan bahwa Kota Batu dikembangkan sebagai kota pariwisata berbasis ECBT yang merupakan kombinasi dari Ecotourism (ET) dan Community-Based Tourism (CBT). Pengembangan Kota Batu sebagai kota pariwisata berpengaruh positif terhadap pertumbuhan lapangan kerja di sektor industri pariwisata sebanyak 1.074 jenis lapangan kerja pada tahun 2013, dan meningkat menjadi 6.183 jenis lapangan kerja pada tahun 2017. Peningkatan lapangan kerja di sektor industri pariwisata ini berdampak pula terhadap penurunan tingkat kemiskinan, di mana persentase penduduk miskin di Kota Batu menurun dari 4,67 persen pada tahun 2013 menjadi 4,31 persen pada tahun 2017. Temuan penelitian lainnya menunjukkan juga bahwa migrasi pencari kerja keluar Kota Batu cenderung rendah, sementara migrasi pencari kerja masuk Kota Batu cenderung tinggi. Penelitian menyimpulkan bahwa pengembangan pariwisata Kota Batu efektif dalam menciptakan lapangan kerja dan penurunan tingkat kemiskinan.
\end{abstract}

Kata kunci: pariwisata berbasis ekowisata dan komunitas; peningkatan lapangan kerja; penurunan kemiskinan

\section{Introduction}

Batu City has been developed as the leading tourist attraction in East Java, Indonesia. In an attempt to develop Batu City as a tourism destination, the local government has established several cooperative projects with some investors to build some artificial tourism destinations. The development policy of Batu City as a tourism destination has resulted in positive influences, such as increasing the LocallyGenerated Revenue of Batu City which constitutes the principal source and creates many job opportunities for local people (Sukmana \& Sari 2017). 
Batu City is the newest autonomous region located in East Java. It consists of three districts, including Batu, Junrejo, and Bumiaji. The vision of spatial management in Batu City is to build the city as a 'Tourism City' and 'Center of Agritourism' in East Java (BPS Kota Batu 2019). The local government in Batu City has committed to developing the city as a tourism city. One of the government commitments in executing the goal has been embodied in budget policy. In five recent years, the policy on budgeting allocated for tourism and cultural development in Batu City is shown in Figure 1.

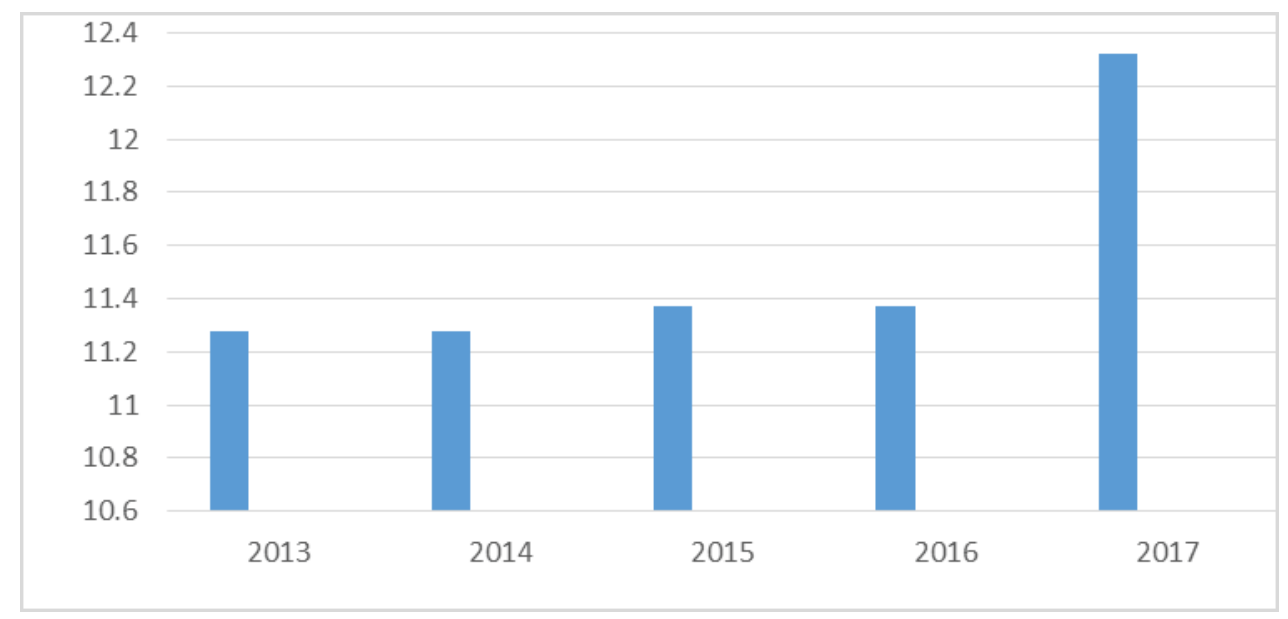

Figure 1.

Budget allocation for tourism and cultural development in Batu City (in billions of Rupiah) Source: BPS Kota Batu (2019)

According to Figure 1, it is evident that the budget policy allocated by the government to support the development of Batu City to be a 'tourism city' signifies IDR 11.277.680.000 in 2013, IDR 11.277.093.000 in 2014, IDR 11.370.048.000 in 2015, IDR 11.370.084.000 in 2016, and IDR 12.321.550.000 in 2017. Based on the shown percentages of the budget for tourism and cultural development, Batu City allocated a relatively small amount from year to year. Besides, based on the Regional Income and Expenditure Budget of Batu City in 2017, only 1.4\% amount was allocated for tourism and cultural development.

Based on that explanation, it seems that the development of Batu City as a tourism destination designate to the combination of Ecotourism (ET) and Community-Based Tourism (CBT), which is then be introduced as Ecocommunity-Based Tourism (ECBT). Some tourist destinations that apply the ECBT model include the Sidomulyo Flower Tourism Village, Lemah Abang (LA) Tourism Village, Bumiaji Apple Picking Tourism Village, Pujon Kidul Tourism Village, and so on. Therefore, this study aims to examine the impact of the development of Batu City as a tourism destination through the EcocommunityBased Tourism (ECBT) model on employment growth and poverty reduction.

According to Damanik et al. (2005), the governments of developing countries have been showing a powerful belief that the tourism industry is of great potential for poverty reduction. The results of some studies conducted in several developing countries have highlighted the real contribution of tourism industry development on job opportunity expansion and poverty reduction (Obour et al. 2017). For example, in Namibia, the development of the Community-Based Tourism (CBT) strategy has been sufficient to alleviate many business activities that improve social empowerment as an attempt to reduce poverty (Lapeyre 2010). Similarly, in Tanzania, the development of Cultural Tourism Programs (CTPs) has worked very well to provide the villagers with a promising probability to gain additional revenue. The strategy of CTPs has been successful in empowering and reducing the numbers of poverty on the local people in Tanzania (Mgonja et al. 2015). Meanwhile, in Costa Rica, the development of the Community-Based Tourism (CBT) model has much contributed to social-economic growth in the countryside (Trejos \& Chiang 2009). 
Cohen (1984) states that there are at least eight concepts related to tourism, including: (1) Tourism as commercialized hospitality, (2) Tourism as democratized travel, (3) Tourism as a modern leisure activity, (4) Tourism as a modern variety of the traditional pilgrimage, (5) Tourism as an expression of basic cultural themes, (6) Tourism as an acculturative process, (7) Tourism as a type of ethnic relations, and (8) Tourism as a form of neocolonialism. The tourism industry is shown to, directly and indirectly, generate multiple effects on social welfare improvement (Gelgel 2006). Many activities are of potentiality to perform under the tourism industry in a country, which is believed to generate more opportunities for service sales (Wahab 2003).

The significant contribution of tourism to the economic development of a country or region may clearly be observed in three forms, which are: (1) the widening of a job opportunity, (2) the increase in the foreign exchange, and (3) the equal distribution of inter-regional development (De Kadt 1979, Mathieson \& Wall 1982). According to Gunawan (Damanik et al. 2005), tourism contributes to poverty reduction by providing employment and diversified living opportunities that improve income and a commensurate decrease in vulnerability. More specifically, tourism can contribute effectively towards sustainable development and the reduction of poverty in many specific ways, including: (1) New opportunities, especially in remote and otherwise marginalized areas that attract visitors, (2) More opportunities for the sale of additional goods and services, (3) Direct taxation and generation of taxable economic growth, (4) The use of valuable resources sustainably through community-based tourism, (5) Improvement of recreation and leisure opportunities for the poor, better labor-intensive, and small scale business opportunities, and (6) Promotion of gender equality in employment opportunities.

According to Pendit (2006), tourism is a new sort of industry that can accelerate economic growth and contribute to job opportunity provision, an improvement in the revenue and other standards of life, and stimulation for different sectors of production. Meanwhile, according to Pitana \& Gayatri (2005), tourism constitutes a direct activity that reaches and involves many people to bring about numerous impacts to the local societies. Cohen (1984) commented that there are eight impact categories generated by the tourism industry upon the socio-economic status of local people consisting of: (1) impact upon foreign exchange gaining, (2) impact upon local people's revenue, (3) impact upon job opportunity provision, (4) impact upon daily needs prices, (5) impact upon financial profit, (6) impact upon ownership and control, (7) impact upon general development, and (8) impact on the governmental revenue.

Ecotourism (ET), as the environmental responsibility of travel and visit to relatively-undisturbed natural areas, aims to enjoy and appreciate nature and promote conservational acts, which has low visitor impact and provides the local people with the meaningful benefit of active socio-economic involvement (Yoder 2017). Ecotourism is defined as a traveling activity of exploring natural spots, with its all-natural authenticity and originality from which some meaningful activities are allowed to perform, such as learning, adoring, and enjoying the scenic nature and biological wealth that consists of hundreds of animals, plants, and local culture around the ecotourism object (Hakim 2004).

According to Damanik \& Weber (2006), three main perspectives of ecotourism include: (1) ecotourism as a product of natural attractiveness, (2) ecotourism as a market of the trip for environmental preservation purposes, and (3) ecotourism as an approach to development, referring to proenvironmental utility and management method on the tourism resources. Ecotourism is also defined as nature-based tourism, which also puts some additional aspects of education and interpretation of nature and societal culture through ecological preservation and management (Fandeli 2001).

Ecotourism, in nature, has six key principles in performing the tourism activities (Haryanto 2014), including: (1) giving experiences and education to the tourists to get them more informed in understanding and appreciating the tourism object they visit, (2) educating the tourists about the essence of natural preservation whilst letting them be more explorative through creative tourism activities along with meaningful services, (3) lessening the negative impacts that might ruin the authenticity of environmental 
and cultural characteristics of the tourism object they visit, (4) involving the community to manage and execute the administration, (5) contributing to economic profit for local people, which should be the main characteristic of ecotourism, and (6) being sustainable and long-lasting. According to Yoeti (2006), ecotourism is defined as the same as the view of Green Tourism Association, stating that tourism industry development is entailed by four main attributes, including: (1) environmental responsibility, (2) local economic vitality, (3) cultural sensitivity, and (4) experimental richness.

Therefore, Community-Based Tourism (CBT) was first proposed as an alternative to mainstreaming tourism development. According to Hausler (2005), there are three pivotal components of CBT, including: (1) the involvement of the local community in tourism management and expansion, (2) economic access equity for all levels of societies, and (3) capacity building on the local people aiming at positioning the local people as a part of decision making.

Lapeyre (2010), said that CBT is an activity that can provide widespread economic and other benefits and decision-making power to communities. Compared to other institutional arrangements in the tourism industry, it is assumed that there are three types of advantages perceived at the local level, that is: (1) rural communities capture most of the revenue generated on-site; thus, there will be very little money leaking out of the local economy, (2) tourism revenue gained by community-based projects and the associated distributed wages generate significant linkages for the local economy; indeed, the money received helps the local families and dependents which will also be spent for local products, and (3) since local inhabitants are fully involved in the management of CBT, rural community members gain institutional and managerial capacities.

CBT constitutes: (1) an understanding to the benefit certainty gained by the community, (2) the assistance for planning attempt which is supposed to give benefits to the local people and other groups of people which have shown great interest or desire to the tourism object, and (3) the management of tourism which facilitates to prepare a greater chance of control for the sake of social welfare around the targeted area (Hudson 1999, Timothy 2002). Anstrand (2006) defined CBT as a sort of tourism that considers and mainly highlights environmental sustainability, social, and culture, in addition to being owned and managed by the community and for the community itself. Suansri (2003) added by defining CBT as a kind of tourism that takes into account aspects such as environment, social, and culture preserved in the community. In essence, CBT is a means of community development and environmental conservation.

Environmental and cultural/social sustainability, local involvement/benefits, social equity, and redistributive justice and control have an important role in ecotourism and CBT (Mtapuri \& Giampiccoli 2018). The concept of ECBT constitutes based on the convergence of ET and CBT concepts. ECBT means that the process of managing the natural environment as a tourism destination involves the role and the participation of the community. The management of the natural environment is integrated with the cultural and social potential to support tourism development.

Srithong \& Saokham (2019) conducted a study on integrated ecotourism and environment for sustainable tourism system planning and development to improve the quality of life of the model community in Chiang Rai Province, Thailand. The results show that this program promotes participation and creates consciousness for all sectors, including government, civil society, private communities, and people of all groups together, conserving, restoring, and enhancing the abundance of natural resources and the environment, promoting the quality of life of people sustainably.

\section{Research Method}

This study used a qualitative research approach (Denzin \& Lincoln 2009). Marvasti (2004) said that qualitative research is supposed to present quality or substantial analysis based on human experiences. Furthermore, this study took place in Batu City, which is named as 'tourism city'. Specifically, the subjects and informants were identified based on a purposive technique (Moleong 2006, Neuman 2007, 
Babbie 2008). The purposive technique is proper for specific conditions in which the researcher is said to take some definite considerations for particular aims. For that reason, the subjects and informants of this study consisted of the staff of Government Tourism Office of Batu City, the Staff of Social Services Office of Batu City, the teams of Central Bureau of Statistics of Batu City, Staff of the Batu City Information and Communications Office, Staff of the Batu City Regional Finance Agency, Staff of Employment Office of Batu City, community group, and business actors in Batu City, such as village tourism management groups, villa management associations, hotel managers, flower traders, tour guides, and so on. The number of informants is eight people.

In this current study, the data were collected through three main methods that interrelate and complete each other, including: documentation, interview, and observation. Documentation sources were obtained from Tourism Government Office, the Central Bureau of Statistics, and the Hotels and Villas Association. Meanwhile, the interview process was carried out with research informants who were determined purposively.

In light of that, qualitative data were gained; therefore, the interpretive approach was used for data analysis. There are some paces of processing qualitative data referring to Babbie (2008) as follows: (1) Coding is referred to as classifying and categorizing data. It is a process of data organization and interpretation through data mapping to a set of categories from which the researcher adopts for conclusion remark and theoretical statement (Kalof et al. 2008), (2) memoing constitutes a process of writing a memo or note for ourselves and those who have involved in the project, and (3) concept mapping is defined as relational mapping on numerous concepts. This mapping can be in the form of a plot, diagram, table, graphic, and so forth.

To validate the data, the researcher focused on credibility and conformability criteria. Credibility covered participation extension, observation perseverance, triangulation, and referential sufficiency. Meanwhile, conformability involved detailed description and truth audit techniques (Moleong 2006). The criteria for the extension of participation are carried out in the process of collecting data directly to the research setting. Meanwhile, the criteria for persistence in observation are carried out in-depth and earnestly on the subject and object of research. The triangulation process was conducted by confirming the data from observations, interviews, and documentation. In addition, the referential sufficiency data was found through the relevant sources related to tourism development models such as journals, books, and other reference sources. The detailed description techniques were explained systematically in the procedures of data collection during the research process. Data analysis was carried out based on the perspective of Miles et al. (2014), which includes the process of data collection, data display, data condensation, and conclusion.

\section{Results and Discussion}

\section{The impacts of the development of Batu City as a tourism destination over the employment growth}

In this section, a description of the impact of the development of Batu City as a tourist city on the growth of employment opportunities will be explained based on data from interviews with informants and documentation obtained from the Central Bureau of Statistics of Batu City. The development of Batu City as a tourist city has a significant impact on employment growth, as stated by the informant as follows:

“...yes, if we refer to the data we have, indeed employment in Batu City from 2013 to 2017 has increased quite significantly. The contribution of job growth in Batu City is mainly from the tourism industry sector. Therefore, tourism development has a positive impact..." (Interview with DAD, a Staff of the Office of Investment and Licensing, Manpower and Transmigration, Batu City, 2018) 
Similar arguments were also stated by SAT, as follows:

“...The policy of the Mayor of Batu to establish Batu City as a tourism city is very appropriate. The growth of employment in Batu City, especially the types of employment related to the tourism industry, is very visible and tangible, for example, the hotel sector, restaurants, tour guide services, and the growth of informal sector employment..." (Interview with SAT, Head of the Information and Communications Agency, Batu City, 2018).

Further, referring to the document of the Central Bureau of Statistics of Batu City, the development impact of Batu City as the tourism destination regarding the employment growth was examined through the following aspects:

First, the Employment Growth Profile of Batu City. The trend of employment growth in Batu City was dominated by the agricultural sector. Nonetheless, along with the stipulated development policy over 'Batu city as a tourism city', there has been found a significantly positive growth on the employment trend generated by the tourism sector since 2013. The growth of the population who are identified to work in agricultural and tourism industries in Batu City is shown in Figure 2.

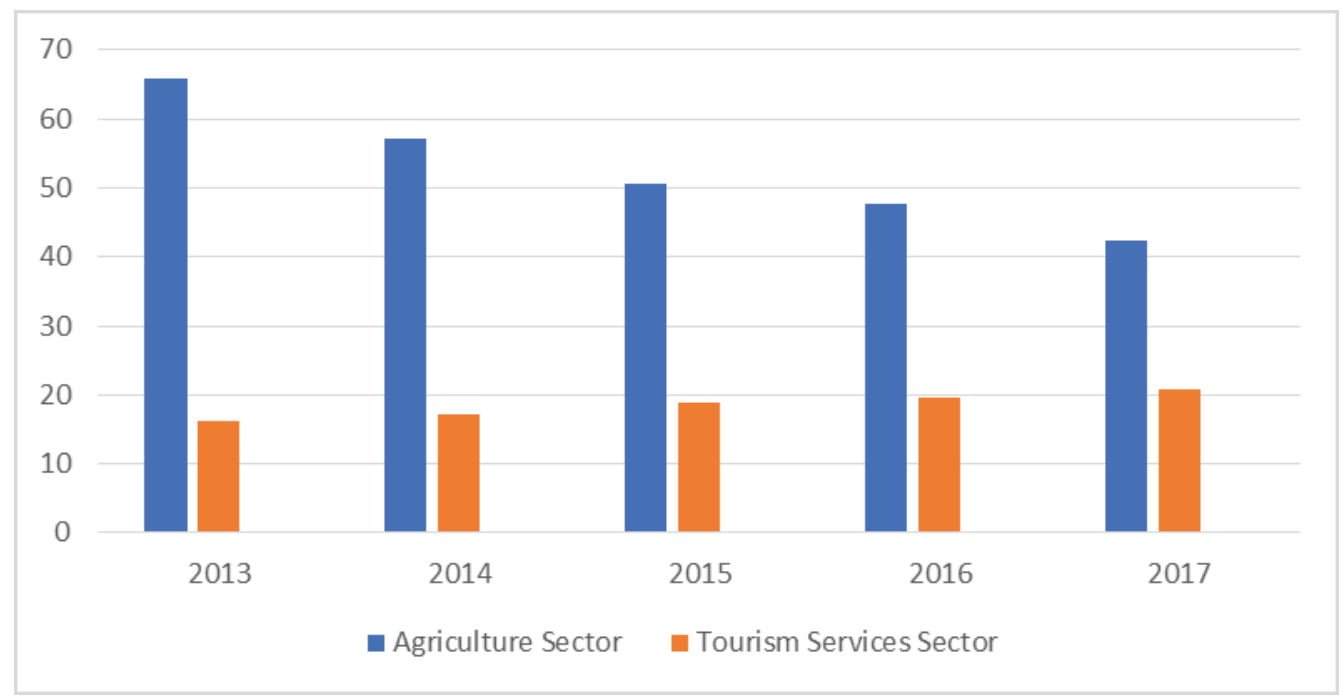

Figure 2.

Population working in the agriculture and tourism service sectors in Batu City (in thousands) Source: BPS Kota Batu (2019)

The number of people working on agriculture in Batu City constituted 67,745 in 2013, 57,253 in 2014, 50,712 in 2015, 47,614 in 2016, and 42,352 in 2017. Meanwhile, those who worked on tourism services in Batu City amounted 16,218 in 2013, 17,129 in 2014, 18,977 in 2015, 19,572 in 2016, and 20,844 in 2017.

Figure 2 shows that the number of people who worked in agriculture had declined by $35.58 \%$ in 2017 compared to that of in 2013. Meanwhile, the number of those who worked on the tourism services had grown up significantly by $28.52 \%$ in 2017 compared to that of in 2013 . This condition occurred to the functional shift of farming land to the tourism area or supporting tourism facilities, such as hotels, villas, amusement parks, and so forth.

“... if we look at the statistical data from 2013 to 2017 in Batu City, there has been a shift in sources of employment from the agricultural sector to the tourism sector. Employment growth in the tourism sector is quite significant..." (Interview with SAW, Staff of the Central Bureau of Statistics of Batu City, 2018) 
Second, the number of working people in Batu City. In five recent years, the growth of employment in Batu City had shown a trend of amelioration. According to reports, the number of working people in Batu City was 101,339 in 2013, 104,177 in 2014, 104,970 in 2015, 106,801 in 2016, and 112.984 in 2017. The growth of the working population in Batu City is shown in Figure 3.

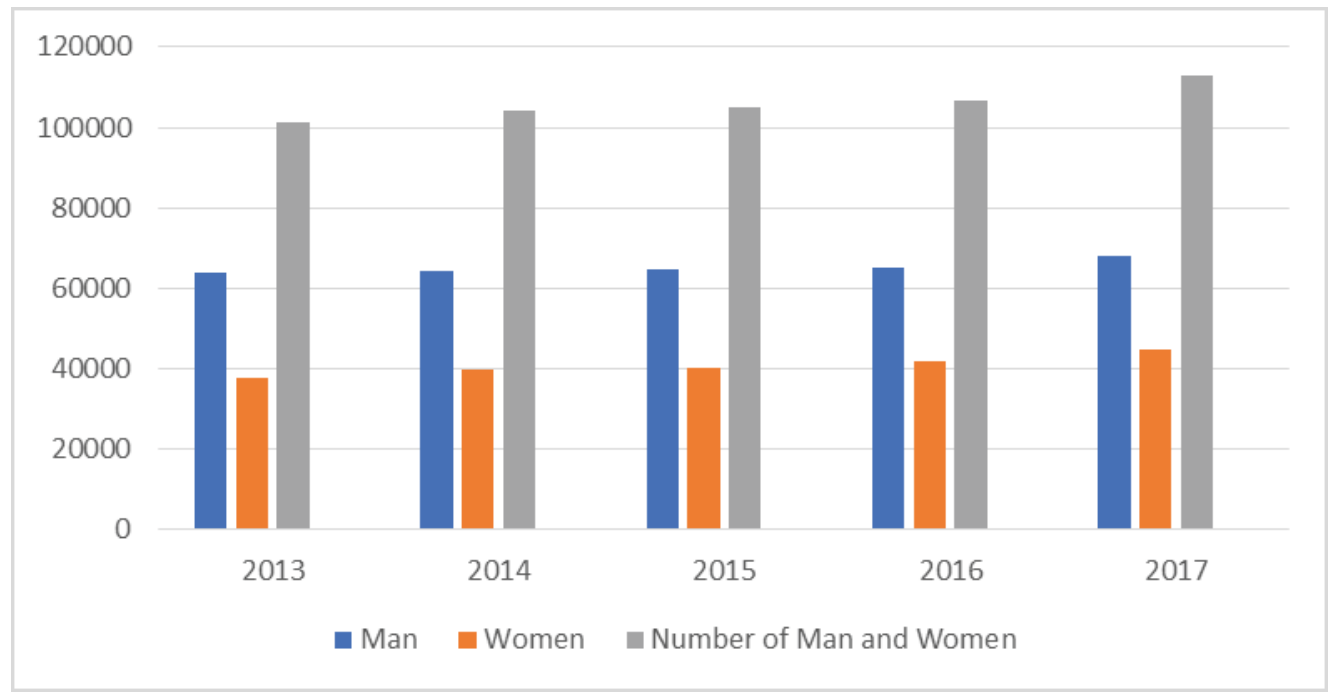

Figure 3.

The development of the numbers of working population in Batu City Source: BPS Kota Batu (2019)

Moreover, the numbers of male and female workers spread over Batu City consecutively showed 63,751 and 37,588 out of 101,339 in $2013,64,259$ and 39,918 out of 104,177 in 2014, 64,557 and 40,413 out of 104,970 in $2015,65,274$ and 41,802 out of 106,801 in 2016 , and 68,182 and 44,802 out of 112,984 in 2017.

An informant stated as follows:

“...the number of people working in Batu City has increased from 2013 to 2017. This increase is due to the increasing number of job opportunities in Batu City as a result of the development of Batu City as a tourism city...” (Interview with PAD, Batu City Manpower Office Staff, 2018)

The highest growth of the working population in Batu City occurred in 2016 and 2017, signifying 6,188 (equal to $5.79 \%$ ). This was due to some factors, including the establishment of new destinations in Batu City, which was deemed contributing to job opportunity expansion, such as Jatim Park-3, Pujon Kidul tourism place, and so forth. As a center of the tourism industry, most of the people in Batu City are working in the supporting sector of the tourism industry, including block trading, street vendor, restaurant, and hotel. In addition, the second most-absorbing sectors of business on employment in Batu City consist of agriculture, forestry, and fishery.

Third, the Employment Growth in Batu City. The employment growth in Batu City has been occurring significantly within five recent years. Such an occurrence is a result of the massive development of tourism destinations in Batu Tourism City. The data of the growth is illustrated in Figure 4.

According to Figure 4, Batu City's employment growth was 1,074 in 2013, 2,778 in 2014, 853 in $2015,1,831$ in 2016, and 6,183 in 2017. Moreover, the highest growth of employment had happened in 2017. This has indicated that the government in Batu City is of total commitment to developing new destinations, which is also supposed to contribute to job opportunity provision, especially on tourism services. 


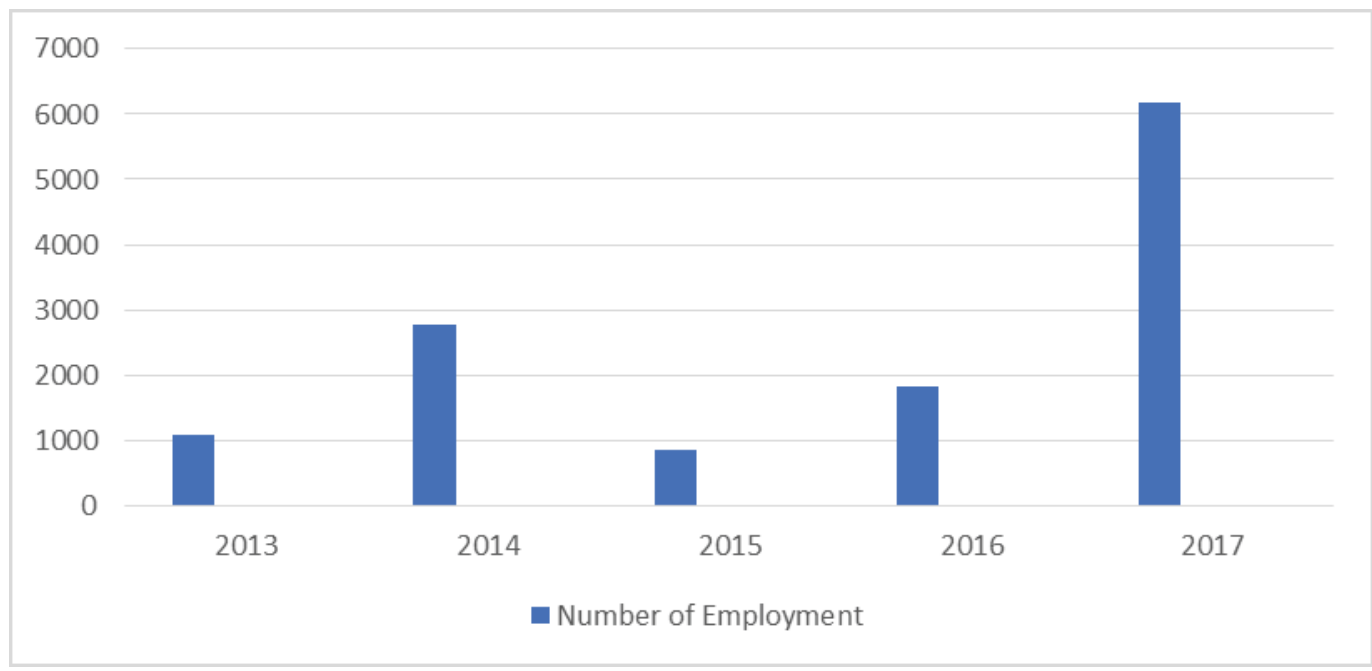

Figure 4.

The employment growth in Batu City

Source: BPS Kota Batu (2019)

Fourth, The Employment Growth of Tourism Services. Another influence of tourism development in Batu City can also be identified through the employment growth of tourism services. Compared to other sectors such as agriculture, the employment growth on tourism services in Batu City had shown great significance. Further, the numbers of workers in tourism services are drawn in the Figure 5.

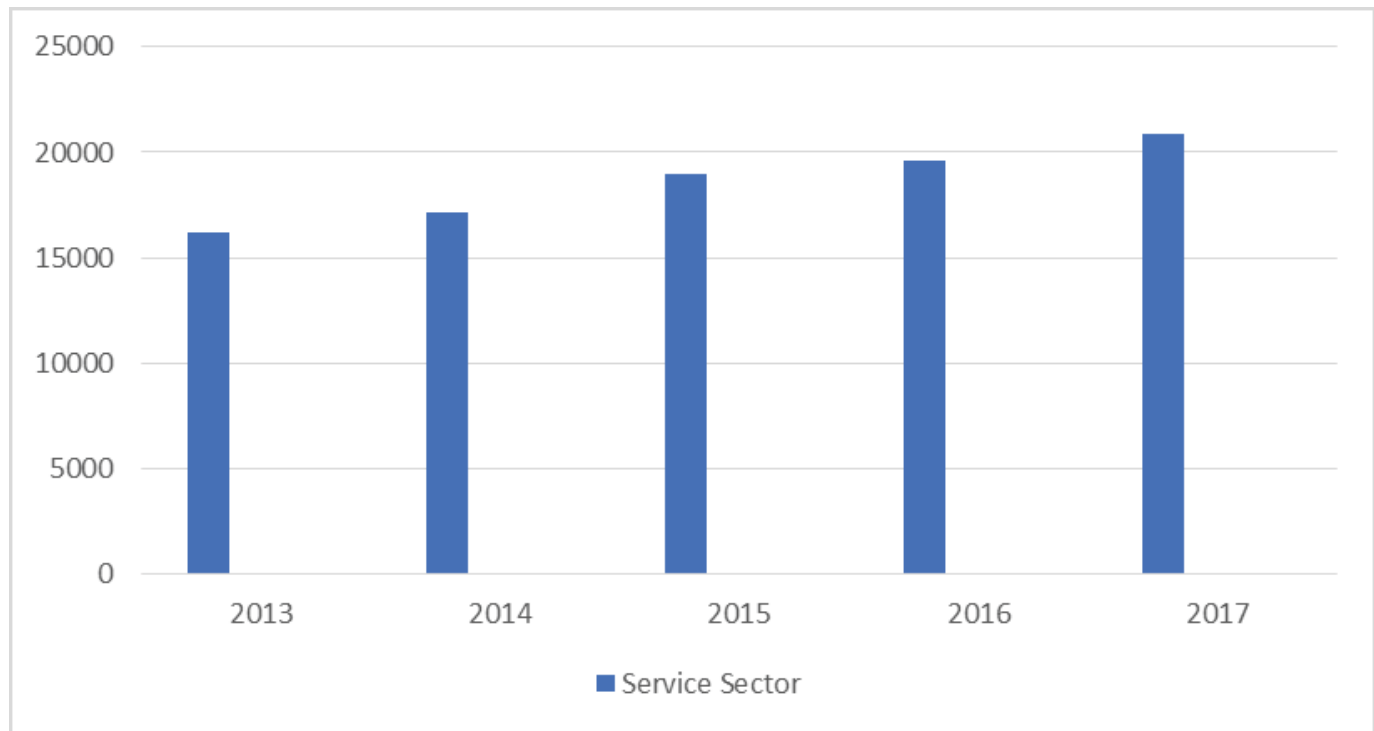

Figure 5.

The development of the numbers of workers on tourism services in Batu City Source: BPS Kota Batu (2019)

Revisiting Figure 5, the percentage of tourism contribution, primarily on tourism services, upon the numbers of employment in Batu City, is obviously detectable. In 2013, the growth of workers in tourism service signified 16,218 , with a growing percentage of $16.01 \%$ from that of 2012 . Further, there were 17,129 workers in 2014 , with a growing percentage of $16.44 \%$ from that of in 2013 . Also, there were 18,977 workers in $2015,18.08 \%$ higher than that of in 2014 . Next, there were 19,572 workers signified in 2015 , with $18,33 \%$ increase from that of in 2015 . At last, 20,844 people worked on tourism services in 2017, which also indicated $18.45 \%$ amelioration from that of in 2016. 
The impacts of the development of Batu City as a tourism destination over the poverty reduction

The policy of the development of Batu City as a tourism city has a positive impact on reducing poverty in the city. The development of Batu City as a tourist city also has a significant impact on reducing poverty rates, as stated by the informant as follows:

“...in the period from 2013 to 2017, if we look at statistical data, the poverty rate in Batu City has a downward trend. This decline in poverty is a positive impact of increasing employment, especially in the tourism sector..." (Interview with BAB, the Head of the Batu City Social Service, 2018)

A similar statement was also said by DAP as follows:

"... as a consequence of the growth in employment in Batu City, the number of people working also increases, so that the unemployment rate decreases and thus also reduces the poverty rate..." (Interview with DAP, Batu City Manpower Office Staff, 2018)

Further, the development impact of Batu City as the tourism destination regarding the poverty reduction was examined through the following aspects: First, the Growth of the Poor Population in Batu City. The increase of the working population in Batu City has shown a close relationship to the decline of the poor population. The numbers of poor population from 2013-2017 consecutively was represented by 940,000 (4.67\%), 910,000 (4.59\%), 907,000 (4.51\%), 905,000 (4.48\%), and 877,000 (4.31\%). The data of the reduction in the poor population can be referred to in Table 1 .

Table 1.

The number of poor population in Batu City

\begin{tabular}{cccc} 
Year(s) & $\begin{array}{c}\text { Poverty line(s) } \\
\text { (IDR) }\end{array}$ & $\begin{array}{c}\text { Number(s) } \\
\text { (people) }\end{array}$ & $\begin{array}{c}\text { Percentage(s) } \\
\text { (\%) }\end{array}$ \\
\hline 2013 & 336,844 & 940,000 & 4.67 \\
2014 & 355,317 & 910,000 & 4.59 \\
2015 & 380,393 & 907,000 & 4.51 \\
2016 & 398,401 & 905,000 & 4.48 \\
2017 & 424,354 & 877,000 & 4.31 \\
\hline \multicolumn{4}{c}{ Source: BPS Kota Batu (2019) } \\
\end{tabular}

In spite of the evident upraise of rupiah's values on the poverty lines, a percentage decrease in poverty was identified. This condition occurred due to the elevation of social welfare in Batu City as a result of job opportunity provision, especially in tourism services.

In accordance with population projection in 2017, there were 203,997 people comprising 102,585 males and 101,412 females. Compared to the numbers of the population in $2016,0.83 \%$ growth had occurred. Meanwhile, the ratio number on gender aspects of male-to-female ratio had indicated by 101 in 2017. The population density, furthermore, in Batu City had reached 4,965 people $/ \mathrm{km}^{2}$ in 2017 . Additionally, the population density in the three districts also varied, in which Batu District was named as the highest with 2,089 people $/ \mathrm{km}^{2}$ and Bumiaji District as the lowest with 903 people $/ \mathrm{km}^{2}$.

Poverty has been a fundamental issue the government is intensively concerned on. The provision of accurate and precise data about poverty is supposed to help the government deal with and try to find a solution to the issue. In fact, it was reportedly found that 8,770 people were living in Batu City in 2017. This was lower than that of in 2016. This decrease was perceived as the result of governmental efforts in finding out effective formulas and programs for poverty reduction in Batu City.

Second, the Poverty Gap Index (P1) and Poverty Severity Index (P2). Poverty Gap Index-P1 is defined as an average parameter of the expenditure gap of the poor people upon the poverty line. The higher the 
index is, the further the expenditure average will be from the poverty line. On the other hand, the Poverty Severity Index-P2 refers to information provision about the disparity of expenditure of the poor people. The illustration on both of the indexes is drawn in Table 2.

Table 2.

\begin{tabular}{ccc}
\multicolumn{3}{c}{ The development of poverty indexes in Batu City } \\
\hline Year & $\begin{array}{c}\text { Poverty Depth Index } \\
\text { (P1) }\end{array}$ & $\begin{array}{c}\text { Poverty Severity } \\
\text { Index (P2) }\end{array}$ \\
\hline 2013 & 0.65 & 0.16 \\
2014 & 0.63 & 0.14 \\
2015 & 0.62 & 0.13 \\
2016 & 0.55 & 0.11 \\
2017 & 0.59 & 0.10 \\
\hline \multicolumn{3}{c}{}
\end{tabular}

Based on Table 2, it is evident that both indexes, P1 and P2, had been decreasing from 2013 to 2017. The decrease of P1 and P2 in Batu City was along with that of percentage shown on the poor population in five recent years.

\section{The impacts of the development of Batu City as a tourism destination to increase local revenue}

The policy of the development of Batu City as a tourist city has a significant impact on increasing the activities of various sectors of the tourism industry. This increase in the activity of the tourism industry sector supports an increase in the aspect of revenue receipts for local governments, especially from the tax revenue sector, as stated by the informant as follows:

“...the main regional income for the Batu City government is in the regional tax revenue sector originating from the tourism industry sector. In the last five years, the development of tourist destinations in Batu City is quite rapid. This is also followed by the development of tourism supporting facilities such as hotels, restaurants, tourist transportation services, and so on..." (Interview with MAS, the Staff of the Batu City Tourism Office, 2018)

Furthermore, another informant stated as follows:

“...the main source of local revenue for Batu City is local taxes, especially taxes from the tourism industry sector. The data shows that there is a significant increasing trend of tax revenue from the tourism industry sector from 2013 to 2017 ..." (Interview with WAU, office staff of the Batu City Regional Finance Agency, 2018)

The development impact of Batu City as the tourism destination regarding the increased local revenue was examined through the following aspects: First, the Growth of Hotels in Batu City. The development policy stipulated in Batu Tourism City had significantly affected the growth of the hotel. The number of hotels in Batu City was 466 in 2013, 489 in 2014, 550 in 2015, 650 in 2016, and 967 in 2017. The additions on the number of hotels manifest the response to the tourists' needs in having a visit to Batu City, which requires them to find out the best hotel to stay overnights. The growth in the number of hotels in Batu City, therefore, can be significantly associated with the growth of employment in the hotel sector.

Second, the Numbers of Tourist Visits to Batu City. Along with the additional tourism destinations in Batu City, there had been an elevation in the growth of tourist visits to Batu City. Data about the number of tourist visits to Batu City in five recent years has fluctuated: 1,881,446 in 2013, 2,089,022 in 2014, $2,412,130$ in 2015, 2,851,217 in 2016, and 4,188,910 in 2017. Averagely, most of the tourists stayed overnight in Batu Malang for 1.3 days, with a one-night length of stay. 
Third, Taxes on hotels, Restaurants, and Folk Entertainment Centers in Batu City. The development policy in Batu Tourism City had significantly influenced the amelioration of the number of hotels, restaurants, and folk entertainment centers. As a consequence, there was also found a significant improvement in tax revenues in those three sectors upon the government of Batu City. The development of hotel tax revenues in the last five from 2013 to 2017 respectively was 6.5, 14.39, 15.64, 17.94, and 19.77 (all the numbers are in billion IDR).

Meanwhile, the development of restaurant tax revenues in the last five years in Batu City had been improving since 2013. In 2016 and 2017, the improvement of tax revenues gained by the restaurant sector was quite significant, constituting $77.65 \%$ in 2016, and $84.93 \%$ in 2017 . Meanwhile, the tax revenues gained from the folk entertainment center in five recent years are shown in Table 3 as follows.

Table 3.

The development of folk entertainment tax revenues in Batu City

\begin{tabular}{cc} 
Year & Folk entertainment tax revenues (IDR) \\
\hline 2013 & $6,296,771,461$ \\
2014 & $6,419,223,859$ \\
2015 & $7,213,112,540$ \\
2016 & $10,023,704,360$ \\
2017 & $14,826,307,547$ \\
\hline
\end{tabular}

Table 3 presents evidence that there was an improvement in the tax revenues gained by the folk entertainment center in Batu City, as the same as that of the restaurant, from 2013. The tax revenue improvement from the folk entertainment center was $38.95 \%$ in 2016 and $47.91 \%$ in 2017 . The percentage of the tax revenue contributed by the hotel, restaurant, and folk entertainment sectors upon the regional income and expenditure budget (APBD) of Batu City in 2017 was 53.04\%, totaling IDR 865 billion.

The results show that the development of Batu City as a tourist city has an impact on the growth of employment opportunities. The results of this study are consistent with those of several other studies conducted in various countries. For example, the results of research by Homafar et al. (2011) in Iran, show that the role of tourism industry development is believed to create jobs and income. In Pakistan, the results of research by Manzoor et al. (2019) show that tourism has a significant positive impact on Pakistan's economic growth and employment sector and that there is a long-term relationship between the variables investigated. This study suggests that due to its great potential, parliamentarians across the country should focus on policies that specifically focus on promoting tourism.

The results of this study showed that tourism development in Batu City is influencing poverty reduction. This situation is consistent with the results of several other studies. For example, Nyataya (2017) conducted a survey in Rwanda, which showed that tourism-related activities helped locals find employment and launch small projects, helping to reduce poverty in the region. In addition, tourism has been observed to help locals develop markets for agricultural and artisan products. Using the primary poverty index, this study showed that tourism improved the general living conditions of the rural population. In China as well, Zhao \& Xia (2019) found that tourism could have a positive effect on poverty reduction, and the resulting inequality in income distribution among the poor could weaken tourism's poverty reduction effect. Likewise in Tanzania, the results of research conducted by Yusuf \& Ali (2018) state that tourism as an industry can play a very important role in economic development, such as livelihood improvement and socio-cultural development, which are essential in the fight against poverty.

Furthermore, the findings of this study indicate that the development of Batu City as a tourism city has an impact on increasing tax revenues from the tourism industry sector. The research conducted by Obalade \& Dubey (2014) in Jordania also shows similar results where tourism had always been recognized as a remunerative industry that positively contributes to a country's GDP, citizens' quality of life and generation of employment. For example, tourism is considered a major pillar in the economy of 
the Country of Jordan; however, Jordan as a nation may need to do more in order to compete globally in this lucrative sector. Tourism is similar to other industries that generate revenue and contribute to a country's GDP and balance of payments. According to the World Travel and Tourism Council (WTTC)'s 2003 statistics, tourism generates around 200 million jobs worldwide and accounts for $10 \%$ of the world's global GDP.

\section{Conclusion}

The development of Batu City as a tourism city had a positive effect on employment growth, which reached 1,074 types of employment in 2013 and increased to 6,183 types of employment in 2017. The increase in employment in the tourism industry sector also has an impact on poverty levels, with the percentage of poor people in Batu City decreasing from 4.67 percent in 2013 to 4.31 percent in 2017. Other research findings also show that the migration of job seekers out of Batu City tends to be low, while the migration of job seekers into Batu City tends to be high. This study concludes that the development of tourism in Batu City is effective in creating jobs and reducing poverty levels.

The development policy of Batu City as a tourism destination using the ECBT concept, which has a positive impact on employment growth and poverty reduction in Batu City, therefore, needs to be maintained and developed further. Due to a large amount of potential development of tourism in Batu City, the government should increase the budget allocation for tourism and culture development by involving the role and participation of society. Furthermore, tourism development is believed to have a positive impact, especially in improving economic conditions and reducing the level of poverty in developing a country like Indonesia. Basically, there are three models of tourism development, including: Ecotourism (ET), Community-Based Tourism (CBT), and Ecocommunity-Based Tourism (ECBT) models. ECBT model, as the newest one, has not been implemented yet as the development model for tourism. Similarly, there is also still very limited literature concerning the concept of ECBT.

\section{References}

Anstrand M (2006) Community-based tourism and socio-culture aspects relating to tourism: A case study of a Swedish student excursion to Babati (Tanzania). http://www.diva-portal.org/smash/get/ diva2:16436/fulltext01.pdf.

Babbie E (2008) The Basics of Social Research. Belmont: Thomson Wadsworth.

BPS Kota Batu (2019) Kota Batu Dalam Angka 2019. [Accessed 05 September 2019]. https://batukota. bps.go.id/publication/2019/08/16/cc143236cd063bd98ecdc875/kota-batu-dalam-angka-2019. html.

Cohen E (1984) The sociology of tourism: Approaches, issues, and finding. Annals of Tourism Research 10:372-392.

Damanik J, Kusworo HA, \& Raharjana DT (2005) Penanggulangan Kemiskinan melalui Pariwisata. Yogyakarta: Kepel Press.

Damanik J \& Weber HF (2006) Ecotourism Planning from Theory to Applications. Yogyakarta: Andi Offset.

De Kadt E (1979) Tourism: Passport to Development? Perspective on the Social and Cultural Effects of Tourism in Developing Countries. New York: Oxford University Press.

Denzin NK \& Lincoln YS (2009) Handbook of Qualitative Research. Yogyakarta: Pustaka Belajar.

Fandeli C (2001) Dasar-Dasar Manajemen Kepariwisataan Alam. Yogyakarta: Penerbit Liberty.

Gelgel IP (2006) Industri Pariwisata Indonesia dalam Globalisasi Perdagangan Jasa (GATS-WTO): Implikasi Hukum dan Antisipasinya. Bandung: Refika Aditama.

Hausler N (2005) Planning for Community Tourism: A complex and challenging task. Conference paper. In: Tourism Forum International at the Reisepavillon the International Ecotourism Society.

Hakim L (2004) Dasar-Dasar Ekowisata. Malang: Bayumedia.

Haryanto JT (2014) Model pengembangan ekowisata dalam mendukung kemandirian ekonomi daerah studi kasus Provinsi DIY. Kawistara Journal 4 (3):271-286. 
Homafar F, Honari H, Heidary A, Heidary T, \& Emami A (2011) The role of sport tourism in employment, income and economic development. Journal of Hospitality Management and Tourism 2 (3):34-37.

Hudson T (1999) Tourism Planning: An Integrated and Sustainable Development Approach. New York: Van Nostrand Reinhold.

Kalof L, Dan A, \& Dietz T (2008) Essentials of Social Research. New Bedford: Open University Press. Lapeyre R (2010) Community-based tourism as a sustainable solution to maximize impacts locally? The case Tsiseb Conservancy, Namibia. Southern Africa Development 27 (5):757-772. https://doi.org/ 10.1080/0376835X.2010.522837.

Manzoor F, Wei L, Asif M, Zia ul Haq M, \& Rehman H (2019) The contribution of sustainable tourism to economic growth and employment in Pakistan. International Journal of Environment Research and Public Health 16 (19):3785. https://doi.org/10.3390/ijerph16193785.

Marvasti AB (2004) Qualitative Research in Sociology: An Introduction. London: SAGE Publications. Mathieson A \& Wall G (1982) Tourism: Economic, Physical, and Social Impacts. The University of Michigan: Longman.

Miles MB, Huberman AM, \& Saldana J (2014) Qualitative Data Analysis, A Methods Sourcebook, $3^{\text {rd }}$ Edition. USA: Sage Publications.

Mgonja JT, Sirima A, Backman KF, \& Backman SJ (2015) Cultural community-based tourism in Tanzania: Lessons learned and the way forward. Journal of Development Southern Africa 32 (3):377-391. https://doi.org/10.1080/0376835X.2015.1010710.

Moleong LJ (2006) Metodologi Penelitian Kualitatif. Bandung: Rosdakarya.

Mtapuri O \& Giampiccoli A (2018) Tourism, community-based tourism and ecotourism: A definitional problematic. South African Geographical Journal 101 (1):22-35. https://doi.org/10.1080/037362 45.2018.1522598.

Neuman WL (2007) Basics of Social Research: Qualitative and Quantitative Approaches. Boston: Pearson Education, Inc.

Nyataya IPK (2017) Tourism a tool for poverty alleviation in Rwanda: Case of Kinigi Sector of Musanze District. International Journal of Research in Sociology and Anthropology (IJRSA) 3 (2):23-37.

Obalade TAF \& Dubey S (2014) Managing tourism as a source of revenue and foreign direct investment inflow in a developing country: The Jordanian experience. International Journal of Academic Research in Economics and Management Sciences 3 (3):16-42. http://dx.doi.org/10.6007/ IJAREMS/v3-i3/901.

Obour R, Ankomah P, \& Larson T (2017) Ecotourism potential in alleviating rural poverty: The case of Kakum National Park in Ghana. Athens Journal of Tourism 4 (4):263-282. http://dx.doi. org/10.30958/ajt.4.4.1.

Pendit NS (2006) Ilmu Pariwisata: Sebuah Pengantar Perdana. Jakarta: Pradnya Paramita.

Pitana I Gd \& Gayatri PG (2005) Sosiologi Pariwisata. Yogyakarta: Andi Publisher.

Srithong P \& Saokham M (2019) The integrated management of planning and eco-sustainable tourism for developing the community model in Chiang Rai Province. The $26^{\text {th }}$ Tri-U International Joint Seminar and Symposium, Jiangsu University, China, October 20 - October 24, 2019.

Suansri P (2003) Community Based Tourism Handbook. Bangkok: Responsible Ecological Social Tours (REST) Project.

Sukmana O \& Sari R (2017) Jaringan sosial praktek prostitusi terselubung di kawasan wisata Kota Batu. Sosio Konsepsia: Jurnal Penelitian dan Pengembangan Kesejahteraan Sosial 6 (2)155-166. https://doi.org/10.33007/ska.v6i2.481.

Timothy DJ (2002) Tourism and Community Development Issues. In: Shapley R \& Teller DJ (ed). Tourism and Development: Concepts and Issues. Toronto: Channel View.

Trejos B \& Chiang LHN (2009) Local economic linkages to community-based tourism in rural Costa Rica. Singapore Journal of Tropical Geography 30 (3):373-387. https://doi.org/10.1111/j.14679493.2009.00375.x.

Wahab S (2003) Manajemen Kepariwisataan. Jakarta: Prandnya Paramita.

Yoder SD (2017) Ecotourism, religious tourism, and religious naturalism. Journal for the Study of Religion, Nature and Culture 11 (3):291-314. https://doi.org/10.1558/jsrnc.32238.

Yoeti OA (2006) Pariwisata Budaya: Masalah dan Solusinya. Jakarta: Pradnya Paramita. 
Yusuf S \& Ali MM(2018) Tourism and poverty reduction: Evidence from Tanzania. International Journal of Asian Social Science 8 (12):1130-1138. https://doi.org/10.18488/journal.1.2018.812.1130.1138.

Zhao L \& Zia X (2019) Tourism and poverty reduction: Empirical evidence from China. Special Issue: Tourism Economics in China: Facing the New Normal. Tourism Economics 26 (2):233-256. https://doi.org/10.1177/1354816619863266. 